\title{
Työelämän tarpeet, sivistys ja elämän laatu -
}

\section{mahdoton yhtälö Euroopan}

\section{koulutusjärjestelmien kehittäjille?}

\author{
KAUKO HÄMÄLÄINEN \& JOUNI VÄLIJÄRVI
}

\begin{abstract}
"On välttämätöntä, että omaehtoinen koulutuspolitiikka nousee päätöksenteossa nykyistä vahvemmaksi suunnannäyttäjäksi sen sijaan, että se on alisteinen talous- ja sosiaalipolitiikalle. Koulutusta koskevilla ratkaisuilla luodaan pitkällä tähtäimellä edellytykset muiden politiikan alojen tavoitteiden saavuttamiselle. Koulutuspolitiikasta vastaavien tulee olla arvokeskustelun ylläpitäjiä, ja kovassa kilpailuyhteiskunnassa humanististen ja sivistyksellisten arvojen vaalijoita", Kauko Hämäläinen ja Jouni Välijärvi kirjoittavat.

Kirjoittajat valmistivat keväällä 2006 opetusministeriölle laajan taustapaperin "EU:n koulutuspolitiikan ja koulutusjärjestelmien haasteet vuoden 2010 jälkeen". Nyt julkaistavassa artikkelissa on hyödynnetty tätä työtä.
\end{abstract}

Koulutuksesta on jo vuosikymmenet etsitty ratkaisua mitä moninaisimpiin yhteiskunnallisiin ongelmiin. Koulutuksen yhteiskunnallinen merkitys vain kasvaa jatkossa. Jo vuoteen 2010 mennessä väestön ikääntymisestäja syntyvyyden alenemisesta aiheutuva työvoimapula pahenee olennaisesti, jolloin aikuisten ja työvoiman ulkopuolella nyt olevien ihmisten uudelleen koulutus ja työkyvyn ylläpito on yhä välttämättömämpää. Tilanne on kaikissa kehittyneissä teollisuusmaissa samankaltainen. Tämä merkitsee kiristyvää kilpailua osaavasta väestä eri maiden kesken.

Tässä vaiheessa näyttää selvältä, että Euroopasta ei tule 2010 mennessä tiedon varaan rakentavaa maailman kilpailukykyisintä aluetta, vaan erityisesti Tyynenmeren ympärysvaltiot etenevät selvästi ripeämmin askelin. Huippuosaaminen ei ole enää eurooppalaista tai pohjoisamerikkalaista erikoisoikeutta, vaan esimerkiksi Intia kouluttaa vuosittain noin 250000 uutta insinööriä. Kiina yltää EU:n tasolle tutkimukseen käytettävissä varoissa vuoteen 2010 mennessä.

Seuraavien neljän vuoden kehittämistarpeet ovat kuitenkin pieniä verrattuna siihen, mitä tar- vitaan vuoden 2010 jälkeen. Esimerkiksi suuret väestörakenteen ja työelämän muutokset sekä bruttokansantuotteen kasvun hidastuminen aiheuttavat sen, että eurooppalainen koulutusjärjestelmä tarvitsee radikaaleja rakenteellisia ja toiminnallisia muutoksia. Syntyvyys laskee 1,5:een yhtä naista kohden. Työelämässä on yli 20 miljoona työntekijää vähemmän vuoteen 2020 mennessä. Samaan vuoteen mennessä tulee olemaan 24 miljoonaa 55-64 vuoden ikäistä työntekijää enemmän. Eurooppalaisten yli 65-vuotiaiden määrän on arvioitu kasvavan 77 prosenttia eli 58:een miljoonaan vuoteen 2050 mennessä.

Osaamiseen, innovaatioihin ja tasa-arvoiseen hyvinvointiin nojaavassa Euroopassa on myös 19 miljoonaa työtöntä, rikkaiden ja syrjäytyneiden määrät kasvavat samanaikaisesti, suuri osa lapsista kylpee yltäkylläisyydessä, mutta kasvava osa elää köyhyydessä. Huumeet, elintasosairaudet, psyykkinen pahoinvointi, opiskeluun sitoutumattomuus ja sosiaaliset häiriöt ovat vakava haaste koko koulutusjärjestelmän toimivuudelle erityisesti monissa Euroopan Unioinin uusissa jäsenmaissa. 
Muuttoliikkeen tuoma monikulttuurisuuden kasvu yhdistyy moniuskonnollisuuteen. Koulutuspolitiikan on otettava kantaa koulujen yhtenäisyyteen. Uskontojen tuntemuksen, suvaitsevaisuuden ja jännitteiden käsittelyn merkitys korostuvat. Eri uskontojen ja niihin liittyvien

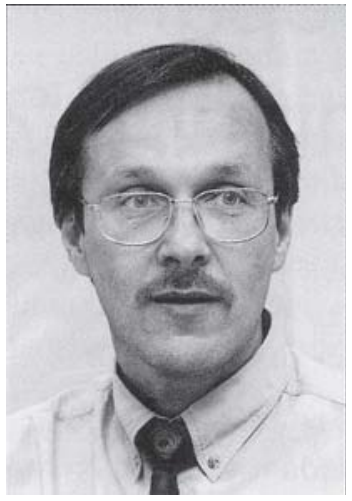

Kauko Hämäläinen

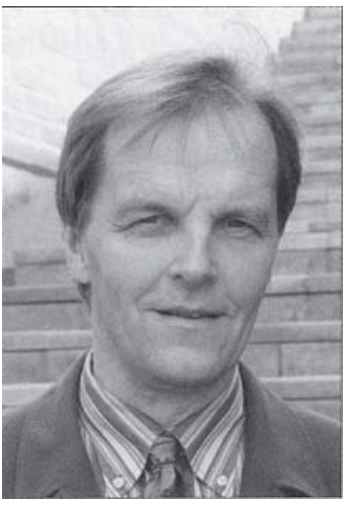

Jouni Välijärvi kulttuurien tuntemus ovat avainasemassa myös kaupankäynnissä, kilpailukyvyssä ja sosiaalisessa kanssakäymisessä. Myös eri maissa syrjäseutujen autioituminen ja niissä pienten koulujen asemaja väestönvanheneminen ovat jatkuvia pohdinnan kohteita.

Koulutus on keskeinen keino torjua ja ratkaista monia taloudellisia, sosiaalisia ja terveydellisiä ongelmia. Koulutuksen perimmäinen yhteiskunnallinen tehtävä on kuitenkin itsearvoinen. Rakentamalla yhteiskunnan sivistyksellistä perustaa sekä syventämällä ja laajentamalla osaamisen varantoa koulutus luo edellytykset sosiaaliselle ja taloudelliselle hyvinvoinnille. Kansakunnan osaamista vahvistavat ja hyvän elämän edellytyksiä edistävät panostukset koulutukseen ovat monin verroin tuottoisampia kuin yritykset hoitaa jo syntyneitä sosiaalisia, työvoimapoliittisia ja terveydellisiä ongelmia koulutuksen keinoin.

\section{Ikääntyvien kansakuntien koko osaamispotentiaali käyttöön}

Väestön ikääntyminen haastaa koulutusjärjestelmiä hyödyntämään nuorten ikäluokkien osaamispotentiaalin nykyistä tehokkaammin. Pelkkä pakollinen peruskoulutus ei enää riitä yhteiskunnan kasvaviin osaamisvaatimuksiin. Koko ikäluokan kouluttaminen vähintään toisen asteen ammatillisiin tutkintoihin on keskeinen tavoite, jotta korkea-asteen opiskelupaikkoihin saadaan riittävä määrä kyvykkäitä opiskelijoita. Tämä on avaintavoite myös pyrittäessä ehkäisemään sosiaalista syrjäytymistä.

Tärkeäksi nousee myös koulutuksen kyky tukea väestön työkykyisyyttä ja työtaitojen ylläpitoa. Erityisesti yli 45-vuotiaille tulisi kehittää koulutus- ja kuntoutuspalveluja, jotta yhä suurempi osa väestöstä selviäisi terveenä eläkkeelle. Koulutus tulee kuitenkin nähdä ensisijaisesti keinona ehkäistä työttömyyttä kuin hoitaa sen seurauksia. Koulutuspalvelut on kyettävä viemään myös osaksi inmisten työtä, mihin tarvitaan pitkäkestoisia yksilöllisiä ja yrityskohtaisia koulutussuunnitelmia.

Elinikä kohoaa edelleen. Tällöin entistä tärkeämpää on se, että vanhukset pysyvät mahdollisimman kauan terveinä ja kykenevinä itsenäiseen elämään ilman laitoshoitoa. Omasta terveydestä huolehtiminen, sairauksien ennaltaehkäisy ja omatoimisuuden vahvistaminen nousevat myös koulutuksen tehtävinä nykyistä keskeisemmiksi.

Monet nuorten terveyttä kuvaavat indikaattorit välittävät hälyttävää viestiä. Elintapoihin liittyvät sairaudet kuten diabetes ja astma, lisääntyvät nopeasti ja niitä havaitaan entistä nuoremmilla. Huumeiden käytön yleistyminen on osa kasvavaa terveysongelmaa. Esimerkiksi sveitsiläisistä 15-vuotiaista nuorista 17 prosenttia ilmoittaa olevansa huumeiden säännöllisiä käyttäjiä (Currie ym. 2004). Kilpailun korostuminen työelämässä heijastuu myös kouluun. Osalla nuoria aleneva henkinen hyvinvointi ja väsyminen ovat lähes pysyvä olotila. Pitkällä tähtäimellä tämä on uhka myös työvoiman tuottavuudelle. Innovatiivinen oppiminen edellyttää riittävän rauhallista ja keskittymisen mahdollistavaa työympäristöä.

Leimallista kehitykselle on nuorten hyvinvoinnin polarisoituminen. Rikkaimman ja köyhimmän viidenneksen välinen kuilu kasvaa. EU:n alueella joka viidettä lasta uhkaa köyhyys. Suurin riski on yksinhuoltajien ja työttömien vanhempien lapsilla. Perheiden tilanne on vaikeutunut ja niiden ongelmat alkavat tulla koulun sisälle tavalla, joita koulut eivät ole tottuneet hoitamaan (Välijärvi 2000). Monissa maissa lasten sisäinen säätelyjärjestelmä ja kehon ja mielen hallinta sekä pitkäjänteisyys ovat selvästi heikentyneet ja käyttäytyminen on entistä kontrolloi- 
mattomampaa. Tämä näkyy lisääntyneenä häiriökäyttäytymisenä, tappeluna ja riitelynä myös tyttöjen joukossa. (Currie ym 2004.) Koulu joutuu paikkaamaan näitä muualla syntyneitä ongelmia.

Työmarkkinoiden muutoksesta seuraa, että koulutusvaatimuksiltaan vähäisten töiden osuus Euroopassa entisestään vähenee ja näiden tehtävien suhteellinen palkkataso heikkenee. Hyvinvointi ja kilpailukyky riippuvat entistä enemmän siitä, kuinka kattavasti ikäluokat onnistutaan kouluttamaan työmarkkinoiden edellyttämiin kvalifikaatioihin(Lehikoinen ym. 2002). Tavoitteena tulee olla kaikkien nuorten koulutuksen ulottaminen vähintään toisen asteen ammatillisen koulutuksen tasolle. OECD:n (2005) selvitykset osoittavat, että ilman työ- tai koululutuspaikkaa olevien nuorten osuus on hälyttävän suuri. Koulutusjärjestelmän kyky houkutella koko ikäluokka ammattiin valmistavaan koulutukseen on monissa maissa jopa heikkenemässä.

Maahanmuuttajat muodostavat monessa Euroopan maassa huomattavan osaamisvarannon, jota koulutusjärjestelmät eivät kykene kovinkaan hyvin hyödyntämään. Maahanmuuttajilla on suuri riski koulun keskeyttämiseen ja siitä seuraavaan syrjäytymiseen. Maahanmuuttajaoppilaat jäävät, lahjakkuudestaan riippumatta, kovin usein heikon koulutuksen varaan. Kielelliset, kulttuuriset ja asenteelliset ongelmat estävät heitä kehittämästä potentiaalista osaamistaan yhteiskunnan ja työmarkkinoiden edellyttämiksi kvalifikaatioiksi. Monissa maissa maahanmuuttajataustaiset nuoret sijoittuvat lähes yksinomaan vähemmän arvostettuihin ja tavoitteiltaan vaatimattomampiin koulumuotoihin ja opiskelulinjoille. Suhteessa valtaväestöön moninkertainen osuus näistä nuorista luokitellaan erityisopetuksen piiriin kuuluviksi. Tämä koskee usein myös sellaisia nuoria, jotka ovat syntyneet Euroopassa ja asuneet siellä koko elämänsä. (OECD 2006.)

\section{Tarvitaan radikaalia pedagogiikan uudistumista}

Työelämän osaamistarpeet muuttuvat nopeasti ja osin ennustamattomasti globalisaation, teknologian ja median kehityksen seurauksena. Työssä vaadittava osaaminen kohdistuu yhä rajatumpiin osiin tuotantoprosessia ja siten asiantuntijuus jakautuu yhä kapea-alaisemmaksi. Toisaalta asiantuntemus voi vanheta tai sen tarve kadota hyvinkin nopeasti. Asiantuntijuuden kehittämi- sessä olennaiseksi nousee taito luoda tehokkaasti uusia yhteistyö- ja kommunikaatiosuhteita erilaista osaamista edustavien ihmisten kanssa. (Suikkanen ym.2002.)

Tarvitaan uudenlaisia informaation käsittelyn ja kommunikaation taitoja, joihin liittyy kyky yhdistellä innovatiivisesti erilaisia tietovarantoja ja tuottaa näin uusia teoreettisia ja tuotannollisia ratkaisuja.

Kilpailukyvyn säilymisen edellytyksenä on, että korkeatasoinen asiantuntijuus on lähtökohtana yhä useampien työtehtävien kvalifikaatioiden määrittelyssä. Tähän liittyy läheisesti myös taito arvioida kriittisesti tiedon pätevyyttä ja soveltuvuutta. Tämän tavoitteen toteutuminen edellyttää koko koulutusketjun tehtävien kriittistä arviointia perusopetuksesta lähtien. Innovatiivinen eurooppalainen talousalue ei rakennu panostamalla pelkästään huippuosaamiseen, vaan sen ensisijaisena edellytyksenä on koko ikäluokan perusopetus tavalla, joka onnistuu saamaan esiin ja aktiiviseen käyttöön nuorten erilaiset lahjakkuusalueet. (Canto-Sperber \& Dupuy 2001: European Commission 2004.)

Teknologian onnistunut pedagoginen käyttö edellyttää huomattavia panostuksia ns. inhimillisen teknologian kehittämiseen. Tämä tarkoittaa ennen kaikkea investointeja uusimman oppimistutkimuksen ja informaatioteknologian sovellusten monitieteiseen tutkimukseen ja sen tulosten tuotteistamiseen koulukonteksteissa. Viimeisimmät tulokset ns. human technology sovellusten pilotoinneista osoittavat, että on mahdollista tuottaa pedagogisesti toimivia tietotekniikan sovelluksia tavalla, joka tavoittaa kaikkien opettajien arkitodellisuuden. Teknologia sinällään ei ole enää sovellutusten este. Tutkijoiden ja opettajien yhteistyöllä tekniset ja asenteelliset kynnykset on mahdollista jo ylittää tavalla, joka edistää teknologian käyttöä opiskelun ja opetuksen uudistamisen välineenä. Tällä tiellä ollaan kuitenkin vielä alkumetreillä ja panostukset teknologian humanisointiin ja pedagogisointiin ovat vielä aivan liian vähäisiä (Järvelä ym. 2006).

On tärkeää ymmärtää se, että "korkeatasoinen osaaminen", "alisuoriutuminen" tai "aktiivinen oppiminen" tarkoittavat sisällöllisesti ja laadullisesti hyvin eri asioita eri inmisillä. Opettajien ammattitaitona korostuu yhä enemmän kyky tunnistaa yksilön oppimisen realistisia mahdollisuuksia ja tukea vaihtelevien keinoin niiden toteutumista. Nuoren itsetunnon kannalta on olen- 
naista opettajien valmius arvostaa tasavertaisesti niin teoreettista, taidollista, käytännöllistä kuin taiteellistakin osaamista ja arvioida osaamisen kehittymistä suhteessa nuoren omiin edellytyksiin.

Keskeiseksi koulutusjärjestelmien laatukriteereiksi nousee niiden kyky luoda myönteistä asennetta oman itsensä jatkuvaan kehittämiseen.

\section{Koulutussektorin otettava johtava yhteiskunnallinen rooli}

Tarve koulutus-, terveys- ja sosiaalipolitiikan koordinoituun kehittämiseen korostuu väestön hyvinvoinnin ja tasa-arvon edellytyksenä. Koordinaation puute syö perustaa myös pitkäkestoiselta ja kestävältä talouden kasvulta, jos pienenevän työikäisen väestönosan panos työmarkkinoilla uhkaa entisestään vähentyä.

Koululla on kasvava rooli väestön terveysosaamisen vahvistajana ja terveydellisten ongelmien ennaltaehkäisijänä. Koulutuksen avulla vahvistetaan hyvinvoinnin resursseja ja tuetaan terveen elämän edellytyksiä, kun muiden yhteisöllisyyttä rakentavien instituutioiden kuten perheen ja kirkon vaikutus on heikkenemässä.

Kansainvälisen taloudellisen kilpailun kiristyessä koulutuksen merkitys kilpailukyvyn edellytysten luojana on korostunut. Samalla kuitenkin on nähtävissä, että koulutus mielletään entistä välineellisempänä instituutiona, ts. keinona taloudellisten arvojen vahvistamiseen. Sama koskee koulutuksen suhdetta moniin muihin yhteiskunnan toimintalohkoihin. Koulutus on poliittisille päättäjille yhä enemmän keino ratkaista esimerkiksi ikääntymisen, puutteellisen ammattitaidon, maahanmuuton tai väestön terveyskäyttäytymisen ongelmia. Koulutuksen itseisarvo yhteiskunnan sivistyksellisten ja inhimillisten arvojen todentajan uhkaa murentua. Koulutus pirstaloituu ja uhkaa kadottaa sivistyksellisen päämääränsä.

On välttämätöntä, että omaehtoinen koulutuspolitiikka nousee päätöksenteossa nykyistä vahvemmaksi suunnannäyttäjäksi sen sijaan, että se on alisteinen talous- ja sosiaalipolitiikalle. Koulutusta koskevilla ratkaisuilla luodaan pitkällä tähtäimellä edellytykset muiden politiikan alojen tavoitteiden saavuttamiselle. Koulutuspolitiikasta vastaavien tulee olla arvokeskustelun ylläpitäjiä, ja kovassa kilpailuyhteiskunnassa huma- nististen ja sivistyksellisten arvojen vaalijoita. Ammattikasvattajien on otettava aktiivinen rooli yhteiskunnan muovaajana ja hyvän elämän rakentajana, kulttuurisen sosialisaation toteuttajana, tasa-arvon edistäjänäja kaikenikäisten tasaarvoisen lahjakkuuspotentiaalin toteuttajana.

Jo lähivuosina Euroopan on määritettävä linjansa kansallisten koulutusjärjestelmien pitkän tähtäimen kehittämiseen. Muussa tapauksessa koulutuksen asema ja sen yhteiskunnallinen vaikuttavuus uhkaa heiketä. Erityisesti perusopetuksen osalta on linjattava sitä, halutaanko koulutusta kehittää kohden yhtenäisempää ja koko ikäluokalle pääosin samansisältöisenä tarjottavaa mallia vai sallitaanko lisääntyvä koulujen muodostuminen esimerkiksi eri väestöryhmien intressien, uskontojen, kielten, kasvatuksellisten ja poliittisten ideologioiden tai lasten erityislahjakkuuden pohjalle.

Paineet eri uskontoihin nojaavien koulujen perustamiseksi kasvavat. Tällöin joudutaan pakosta ottamaan kantaa siihen, miten painotetaan koulutuksen tehtävää yhtäältä sosiaalisen koheesion, yhteiskunnallisen integraation ja kulttuurien välisen vuorovaikutuksen edistäjänä ja toisaalta sen roolia kulttuurisen moninaisuuden, suvaitsevaisuuden ja rinnakkaisten arvomaailmojen vaalijana. Eurooppalaisen koulutuspolitiikan keskeisiä kysymyksiä on, mitä tarkoittaa "eurooppalainen identiteetti" ja millä koulutuksellisilla ratkaisuilla sitä pyritään vahvistamaan. Erityisesti kansalaiskasvatus (civic education) ja kielten opetus nousevat tällöin avainasemaan.

Ollakseen uskottavaa ja yhteiskunnallisesti vaikuttavaa koulutuspolitiikan tulee perustua monipuoliseen, luotettavaan ja riippumattomaan tietoperustaan. Nykyisin kovin vähäistä koulutuksen taloutta koskevaa tutkimusta tulee kehittää monitieteisesti niin, että tutkimuksessa yhdistyvät taloustieteen, kasvatustieteen sekä yhteiskunta- ja sosiaalitieteiden näkökulmat koulutukseen. Tämä on edellytys sille, että koulutuksen vaikuttavuutta voidaan tarkastella riittävän monipuolisesti ja pitkällä aikavälillä.

Myös mittava eurooppalainen tilastotuotanto on saatava paremmin koulutuspoliittista päätöksentekoa hyödyntämään. Nykyistä koulutusta kuvaavat indikaattorit tavoittavat vielä varsin kapea-alaisesti ja puutteellisesti koulutuksen tulokset ja niihin yhteydessä olevat resurssi- ja kontekstitekijät. 


\section{Enemmistökö korkeakouluihin?}

Työelämän muutos edellyttää yhä useammilta työntekijöiltä yhä vaativampaa osaamista. Osaamisen merkityksen kasvu näkyy työmarkkinoilla. Työelämä rekrytoi yhä enemmän Euroopassa korkeasti koulutettuja. Korkeaan osaamiseen perustuvien ammattiryhmien kuten tuotannon ja liikenteen johto- ja asiantuntijatyön, talouden ja hallinnon johto- ja asiantuntijatyön sekä opetus ja kulttuurityön työvoiman on arvioitu kasvavan seuraavien vuosikymmenten ajan. Erityisesti tarvitaan uuden tuotannollisen potentiaalin luomiseen liittyvää osaamista. Näin uuden työvoiman tarve on suuri useimmilla yhteiskunnan lohkoilla, esimerkiksi sosiaali- ja terveysaloilla, opetusja kulttuurialoilla. Palvelutyön kasvu jatkuu, niiden laatu kehittyy ja tarjonta monipuolistuu. Palvelutyön kilpailukyvyn edellytyksenä korostuvat ajantasainen osaamisen ohella yhä enemmän sosiaaliset ja markkinointitaidot. (Suikkanen ym. 2002)

Osaamistason tarve nousee lähes kaikissa työtehtävissä osittain ilman, että se edellyttää varsinaisesti aiempaa korkeampaa koulutusta. Toisaalta ammattirakenne muuttuu niin, että se edellyttää korkeampaa koulutusta ja osaamista. Euroopassa kolmasosa työvoimasta (80 miljoonaa) on vain peruskoulutuksen varassa. On arvioitu, että 2010 mennessä noin puolet uusista tehtävistä edellyttää kolmannen asteen koulutusta, lähes 40 prosenttia toisen asteen koulutusta ja vain 10 15 prosenttia edellyttää perusasteen koulutusta. (Palvelut 2020; European Commission 2006)

Eurooppalainen koulujärjestelmä ei vielä monessakaan maassa kykene tuottamaan riittävästi korkea-asteen tutkintoja. Korkeakoulupaikkojen nopeaa lisäämistä on perusteltu tietoyhteiskunnan osaamistarpeilla ja lahjakkuuspotentiaalin mahdollisimman hyvällä hyväksikäytöllä. Ylimpien koulutuspaikkojen lisääminen on johtanut siihen, että toisen asteen ammatilliseen koulutukseen on ollut vaikea enää rekrytoida riittävän hyviä opiskelijoita, joilla olisi riittävä aikaisempi koulutuspohja ja oppimiskyky ja -motivaatio. Tämä näkyy myös melko suurina opintojen keskeyttämisen määrinä (OECD 2006).

EU on selvästi jäljessä Japania ja USA:ta molemmissa. USA:ssa esimerkiksi 18-vuotiaista osallistuu 40 prosenttia korkeakoulutukseen, kun Euroopassa luku on vain noin 20. Euroopassa aloitetaan korkeakouluopinnot selvästi myöhem- min kuin USA:ssa. Eurooppalainen korkea-asteen koulutus on edelleen enimmäkseen erillään liike-elämästä. Korkeakoulujen erilaistuminen jatkuu ja kilpailu kiristyy erityisesti amerikkalaisten yliopistojen vallatessa markkinoita Euroopasta. Jakautuminen houkutteleviin ja kilpailtuihin tutkimusyliopistoihin ja opetukseen keskittyviin (alueellisiin) yliopistoihin voimistuu. Suuri ongelma Euroopassa on se, että kustannukset per yliopisto-opiskelija on vain puolet siitä, mitä USA:ssa. Valtioiden käyttämissä rahamäärissä ei ole eroja, mutta yksityisen rahoituksen suhteen syntyy ratkaiseva ero. Amerikkalaiset hyötyvät paljon siitä, että noin 120000 eurooppalaista tutkijaa toimii sikäläisissä yliopistossa. Myös perustutkimusta on resursoitu olennaisesti paremmin USA:ssa. Rakenteellinen ongelma Euroopassa on opintonsa aloittaneiden korkea ikä, joka on keskimäärin 23 vuotta.

Iso ratkaistava ongelma on korkeakoulujen ja ammatillisen koulutuksen välinen määrällinen jakautuminen ja niissä eri alojen painotukset. Työvoimatarpeiden ennusteiden perusteella tyypilliseltä näyttää voimakas johto- ja asiantuntijatyön kasvu sekä talouden ja hallinnon että tuotannon ja liikenteen alalla. Näin korkeaa koulutusta vaativat asiantuntijatehtävät, jotka edellyttävä korkeakoulututkintoa, lisääntyvät. Tulevaisuudessa on tärkeää, että voimakkaasta kahtiajaosta yleissivistävään ja ammatilliseen koulutukseen luovutaan, ja tarjotaan kaikille nuorille riittävän laaja teoreettinen ja ammatillinen koulutus.

Eurooppalaisten koulutusjärjestelmien yksi kulmakivi on se, että opettajankoulutukseen saadaan ikäluokan parhaita edustajia, heille annetaan mahdollisimman hyvä koulutus ja heidän ammattitaidon jatkuvasta kehittymisestä pidetään huolta. Monissa maissa näkyvissä oleva opettajapula on vakavin uhka tälle kehitykselle. Yhtenä keinona tilanteen korjaamiseksi on opettajan työn arvostuksen ja ammatin statuksen nosto. Tässä Suomella on hyvät edellytykset toimia suunnannäyttäjänä. Onhan meillä opettajan ammatin suosio pysynyt poikkeuksellisen korkeana (Välijärvi 2005). Tähän vaikuttaa palkkauksen ohella se, minkä tasoisissa oppilaitoksissa heitä koulutetaan. Niissä maissa, joissa opetus tapahtuu yliopistoissa, saadaan erityisesti hyviä naishakijoita hakeutumaan alalle.

Euroopan unionin onkin pidettävä opettajan asemaa ja heidän asiantuntijuutensa ja urakehi- 
tyksensä jatkuvaa vahvistamista yhtenä keskeisimmistä prioriteeteista. Opettajankoulutuksen periaatteina täytyy olla näkemys siitä, miten tuetaan opettajuutta, joka edistää aktiivista, omaaloitteista ja kriittistä asennetta tietoon ja uuden osaamisen hankkimiseen.

Myös opettajien elinikäisestä koulutuksesta on huolehdittava. Monissa maissa on selviä puutteita opettajien peruskoulutuksen ja täydennyskoulutuksen integroinnissa. Uran eri vaiheiden tarpeet on hyvä ottaa huomioon. Esimerkiksi uran alkuvaiheissa tarvitaan usein opettajien ohjausta (mentorointia), myöhemmin aineenhallinnan ajan tasalla pitoa ja yli 45-vuotiaille tukea työssä jaksamiseen ja hengenpalon ylläpitoon (Jokinen \& Välijärvi 2006).

\section{Aikuiskoulutuksen merkitys kasvaa}

Aikuiskoulutuksessa poliittinen retoriikka ja arjen todellisuus ovat usein kaukana toisistaan. Elinikäinen oppiminen on yksi Euroopan työllisyysstrategian painopiste. Käytännössä eteneminen on ollut useimmissa jäsenmaissa verkkaista. Aikuiskoulutus on selvästi jäljessä tavoitteista ja maiden väliset erot ovat erittäin suuret esimerkiksi osallistumisen ja järjestelyjen suhteen. Kustannusten jakautuminen aikuiskoulutuksessa on yksi suuri ongelma. Jos se jätetään pelkästään markkinavoimien toteutettavaksi ja osanottajien maksettavaksi, huomattava osa työvoimasta voi jäädä uusia kvalifikaatioita luovan koulutuksen ulkopuolelle, mikä lisää eriarvoisuutta.

Toimet ovat useissa maissa keskittyneet joko työllistyvyyden edistämiseen tai järjestelmistä vieraantuneiden uudelleen aktivoimiseen. Muutamassa Euroopan maassa noin 40 prosenttia työssäkäyvistä eli sama osuus kuin USA:ssa osallistuu vuosittain aikuiskoulutukseen. Joissakin maissa luku on vain 10 prosenttia. Koulutusmahdollisuudet jakautuvat epätasaisesti. Ne ovat parhaat suurissa firmoissa, julkisella sektorilla ja pysyvässä työsuhteessa sekäylemmissä asemissa työhierarkiassa olevilla. (Dosi etc. 2005; Adult learning)

Matalasti koulutettujen ja eri riskiryhmien osallistuminen on todella matalaa. Korkean peruskoulutuksen saaneet osallistuvat kuusi kertaa enemmän aikuiskoulutukseen kuin matalasti koulutetut. Osallistuminen vähenee yleensä melko jyrkästi jo 40 ikävuoden jälkeen. Tulevaisuudessa kuitenkin työkyvyn ylläpito edellyttää, että myös yli 45-vuotiaat pitävät huolta jatkuvasta määrätietoisesta itsensä kehittämisestä. Pienenevien ikäluokkien takia työssäoloaikaa on nostettava useilla vuosilla nykyisestä. Ammattitaidon ylläpidon lisäksi edellytetään myös työssä jaksamisen tukemista. Entistä enemmän on tarvetta myös koulutukseen, joka tukisi aktiivista eläkeikää.

Aikuiskoulutuksen avulla voidaan reagoida nopeisiin työelämän rakenteellisiin muutoksiin, jotka liikuttelevat työvoimaa alalta ja alueilta toisille sekä ammatista toiseen. Lähes jokainen työssä oleva joutuu vaihtamaan useamman kerran elämässään uudelle alalle, johon hänellä ei välttämättä ole koulutusta. Yhden tutkinnon tuoma osaaminen ei riitä enää kovin pitkäksi aikaa työuraa, vaan työssä olevat joutuvat hankkimaan lisäosaamista sekä kouluttautumalla omaa tutkinnon tasoaan korkeammalle että hankkimalla koulutusta muulta kuin peruskoulutuksensa alalta. Työtehtävien vaihtaminen edellyttää järjestelmää, joka mahdollistaisi osaamisen syvällisen uudistamisen 10-15 vuoden välein.

Edellisestä seuraa, että aikuiskoulutus on nostettava lapsi- ja nuorisokoulujen rinnalle tasavertaisesti resursoiden. Sitä tulee suunnitella omana kokonaisuutena palvelemaan niiden alueilla toimivaa elinkeinoa ja julkishallintoa ja vastattava alueiden kehittämistarpeisiin. Aikuiskoulutus ei voi olla enää puutteiden paikkaaja, vaan sillä on omat koulutusfunktionsa ja -strategiansa. Koulutuksen ja työn tulee voida vuorotella entistä tasaisemmin koko työelämän läpi. Tarvitaan myös selkeät järjestelmät epävirallisen oppimisen ja arkioppimisen validointia varten.

\section{Lähteet}

\section{Adult learning: It is never too late to learn.} (2006). Bryssells. Communication from the Comission.

Canto-Sperber, M. \& Dupuy, J.P. (2001). Competencies for the good life and the good society. Julkaisussa D.S. Rychen \& L.H. Salganik (toim.) Defining and selecting key competencies. Göttingen: Hogrefe \& Huber, pp. 67-92.

Dosi, G., Llerena, P. \& Labini, M. (2005). Evaluating and comparing the innovation performance of the United States and the European Union. Expert report prepared for the Tren- 
dChart Policy Workshop 2005.

European Commission (2004). Key competences for lifelong learning, a European reference framework. Brussels.

European Commission (2006). Efficiency and equity in European education and training systems. Brussels. 8.9.2006.

European Commission (2006). Creating an innovative Europe. Report of the Independent Expert Group on R \& D and Innovation appointed following the Hampton Court Summit. http://europa.eu.int/invest-in-research/

Hämäläinen, K. \& Välijärvi, J. (2006). Challenges of EU education policy and education systems after 2010. Opetusministeriö. High level group on education.

Jokinen, H. \& Välijärvi, J. (2006). Making mentoring a tool for supporting teachers' professional development. Teoksessa R. Jakku-Sihvonen \& H. Niemi (Toim.) Research-based teacher education in Finland. Turku: Finnish Educational Research Association, 89102.

Järvelä, S., Häkkinen, P. \& Lehtinen, E. (toim. 2006). Oppimisen teoria ja teknologian opetuskäyttö. WSOY.

Lehikoinen, A., Saarniaho, R. \& Suikkanen, A. (2002). Oppimisella osallisuutta - vastauksia työn murrokseen. Raportteja 29. Sitra. Edita Prima Oy.

Nummenmaa, A.R. \& Välijärvi, J. (2006). Opettajan työ ja oppiminen. Jyväskylän yliopisto. Koulutuksen tutkimuslaitos.

OECD (2001). Knowledge and skills for life. First results from PISA 2000. OECD.
OECD (2004). Education at a Glance. OECD Indicators 2004. OECD.

OECD (2006). Where immigrant students succeed-A comparative review of performance and engagement in PISA 2003. OECD.

Palvelut 2020. Osaaminen kansainvälisessä palveluyhteiskunnassa. Elinkeinoelämän keskusliitto 2006.

Rychen, D.S. \& Salganik, L.H. (toim. 2003). Key competencies for a successful life and well-functioning society. Göttingen: Hogrefe \& Huber.

Torney-Purta, J., Lehman, R., Oswald, H. \& Schulz, W. (2001). Citizenship and education in twenty-eight countries. Civic knowledge and engagement at age fourteen. The International Association for the Evaluation of Educational Achivement. Delft Nederland: Eburon.

Suikkanen, A., Linnakangas, R. \& Martti, S. (2002). Työllisyyden muutos ja koulutuksen merkitys. Aikuiskasvatus, 2, 114-123.

Tulevaisuuden verkottuva Suomi (2005). Tietoyhteiskuntaneuvoston raportti.

Välijärvi, J. (toim.) (2000). Koulu maailmassamaailma koulussa. Haasteet yleissivistävän opetuksen ja opettajankoulutuksen tulevaisuudelle. Opetushallitus.

Välijärvi, J. (2005). Muutoksen kohtaaminen opettajan työssä. Teoksessa O. Luukkainen \& R. Valli (toim.) Kaksitoista teesiä opettajalle. PS-Kustannus, 105-120.

Willms, J.D. (2003). Student engagement at school. A sense of belonging and participation. Results from PISA 2000. OECD. 